\title{
NOTE
}

\section{Differentiation of BP-type baculovirus strains using in situ hybridization}

\author{
S. Durand ${ }^{1, *}$, D. V. Lightner ${ }^{2}$, J. R. Bonami ${ }^{1}$ \\ 'UMR 219 CNRS/IFREMER, UMII, Place E. bataillon, F-34095 Montpellier Cedex 05, France \\ ${ }^{2}$ Department of Veterinary Science and Microbiology, University of Arizona, Tucson, Arizona 85721, USA
}

\begin{abstract}
BP-type viruses infect wild and farmed shrimp species in the Americas and can cause high mortality in larval stages. Histologically, BP disease is characterized by the presence of occlusion bodies (OBs) in the nucleus of hepatopancreatic epithelial cells. By in situ hybridization using different molecular probes, we tested shrimp infected with BPtype viruses collected from several geographical areas. In one shrimp, a case of double infection by 2 different BP-type viruses was noted. This has not been previously reported. The molecular probes recognized only the Pacific strain of BP. This specificity of the probe was confirmed by in situ hybridization tests with some infected shrimp collected from the Atlantic and Pacific coasts. The probes reacted only with infected shrimp obtained from the Pacific coast. These results suggest the existence of at least 2 different BP-type viruses and show that specific probes can be used to differentiate between them.
\end{abstract}

KEY WORDS: Baculovirus $\cdot \mathrm{BP} \cdot$ In situ hybridization $\cdot$ Nonradioactive probes Shrimp

Originally named BP (Baculovirus penaei) by Couch (1974a, b), the baculovirus PdSNPV was first reported in wild populations of Penaeus duorarum from the Northern Gulf of Mexico. It was partially characterized by Summers (1977). Bonami et al. (1995) cloned some genomic fragments from a BP strain (PvSNPV) infecting Penaeus vannamei. This was followed by the application of cloned viral DNA as non-radioactive probes for use as diagnostic tools, both by in situ hybridization and with dot blot methods (Bruce et al. 1993). The BP-type baculoviruses are rod-shaped and enveloped viruses. They are occluded within tetrahedral occlusion bodies (OBs) and they replicate in the nuclei of hepatopancreatic and midgut epithelial cells. Viral replication involves nuclear hypertrophy, followed by nuclear disruption, which ends with the release of free virions and $\mathrm{OBs}$ into the lumen of the digestive

•E-mail: bonami@crit.univ-montp2.fr tract. Based on morphological and biological studies of BP-type viruses from different shrimp populations in the Americas, Lightner et al. (1985) distinguished 3 (or possibly 4) different BP strains: 1 strain from the Gulf of Mexico, 1 from Hawaii and 1 from the Eastern Pacific. A fourth strain of BP may be present in the western Atlantic off Brazil. The present note reports on the possible development of gene probes to distinguish some different BP strains.

Materials and methods. DNA labeling: A library of PvSNPV DNA was constructed in 1982 by Bonami et al. (1995). Two inserts from different areas of the genome were selected to be used as gene probes for in situ hybridization. These cloned DNA fragments were labeled by incorporation (random primed method) of DIG11-dUTP using a DIG DNA labeling and detection kit (Boehringer, Mannheim). Four probes (H6, H2.5, H2, E3) were constructed from these 2 large cloned fragments. All the probes were specific to PvSNPV and no homology was evident among them.

Tissues tested and in situ hybridization: Shrimp infected with BP-type viruses obtained from several geographical regions (Brazil, Ecuador, El Salvador, Florida (USA), Mexico, Panama) were tested. Shrimp were fixed in Davidson's fixative according to Bell \& Lightner (1988) and paraffin-embedded. Sections ( $4 \mu \mathrm{m}$ thick) were mounted onto positively charged microscope slides (Superfrost/Plus, Fisher Scientific) and were used for in situ hybridization using digoxigenin labeled probes according to Bruce et al. (1993).

Results and discussion. In one specimen (Penaeus vannamei) from a shrimp farm on the Gulf of Guayaquil (Ecuador), a peculiar heterogeneous labeling was noted: the hepatopancreas showed some well-labeled nuclei (highly positive reaction of the nucleoplasm) together with other obviously infected nuclei exhibiting distinct occlusion bodies that remained unlabeled (Figs. $1 \& 2$ ). Usually when the reaction is positive, the 


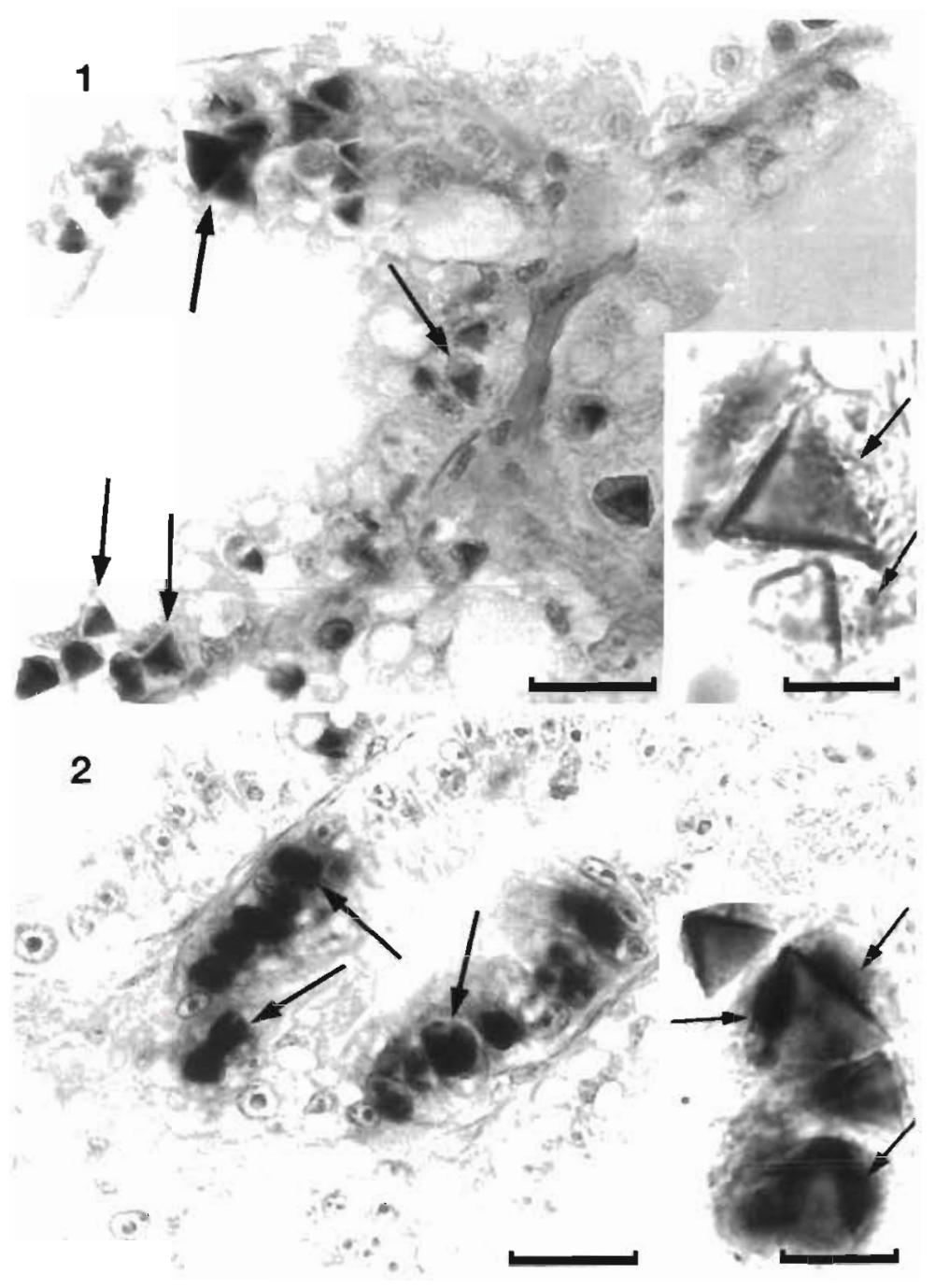

Figs. 1 \& 2. In situ hybridization of a BP-infected specimen with a Dig-labeled probe. Fig. 1. Hepatopancreatic tissue showing no hybridization in the nucleoplasm of epithelial cells, although the presence of OBs (arrows) in hypertrophied nuclei indicates a patent BP-type infection. Scale bar $=20 \mu \mathrm{m}$. At higher magnification (inset), the virogenic area in the nucleoplasm can be seen not to react with the probe. Scale bar $=10 \mu \mathrm{m}$. Fig. 2. Hepatopancreatic tubules show darkly

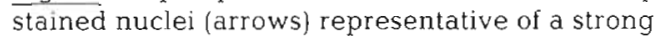
positive hybridization reaction. Scale bar $=20 \mu \mathrm{m}$. At higher magnification (inset), only the virogenic area of the nucleoplasm is labeled (arrows) Scale bar $=10 \mu \mathrm{m}$

(regional or international) of shrimp or another Pacific strain of BP that is not morphologically different.

Double infections by different viruses in the same specimen have already been reported in crustaceans for a baculovirus and a reovirus (Bonami 1980, Mari 1987, Krol et al. 1990). By contrast, double infections with 2 different strains from the same viral family have not been previously noted, probably due to the inability to distinguish different strains or to the lack of suitable tools to recognize them.

The probes used in this study were constructed from DNA of the Pacific strain of PVSNPV (Bonami et al. 1995). Therefore, we assume the probe is specific to the Pacific BP-type. To confirm this hypothesis, studies were done by in situ hybridization on BPtype infected shrimp sections collected on

OBs are not labeled because the probe cannot penetrate into the polyhedral crystal that makes up the $O B$ and only free (non-occluded) virions, plus the virogenic area of the nucleoplasm (total in patent infections), react with the probe. What was astonishing was the negative reaction of hypertrophied nuclei containing OBs indicative of BP infection. To explain the apparent disparity in probe specificity, we hypothesized that insufficient deproteinization by proteinase $\mathrm{K}$ or a poor hybridization of the probe had occurred during the hybridization procedure. However, examination of numerous slides revealed that the unlabeled areas were always located in the same place in the tissues. This result indicated that 2 different BP-type baculoviruses were present in the same specimen and that our probes hybridized with only one. We suppose that the BP-type baculovirus which did not hybridize with our probes could be either a BP strain from the Gulf of Mexico or from Hawaii introduced by transport the 2 coasts of the Americas (Atlantic and Pacific). Of 3 shrimp tested from the Atlantic, all the hybridization assays were negative. OBs were present, but no posi-

Table 1 Reaction of BP probes (H6, H2.5, H2, E3) to BPinfected penaeid shrimp tissue from the 2 coasts of America using in situ hybridization assays. "Cultured and infected in Brazil but imported as post-larvae from Taiwan. Two slides were tested for each species

\begin{tabular}{|lllll|}
\hline Penaeusspp. & Origin & State & Reaction & OBs \\
\hline P. aztecus & Atlantic & Florida & Negative & Present \\
P. vannamei & Atlantic & Brazil & Negative & Present \\
P.penicillatus & Atlantic & Brazil & Negative & Present \\
P. vannamei & Pacific & Ecuador & Positive & Present \\
P. vannamei & Pacific & Panama & Positive & Present \\
P. vannamei & Pacific & El Salvador & Positive & Present \\
P. stylirostris & Pacific & Mexico & Positive & Present \\
P. vannamei & Pacific & Panama & Negative & Absent \\
& & & & \\
\hline
\end{tabular}


tive hybridization was observed. In contrast, 3 of 4 shrimp tested from the Pacific showed positive reactions while the fourth, with no OBs, was negative (Table 1). This study suggests that the 4 probes tested are specific for a Pacific strain of BP, that more than one BP-type baculovirus exists, and that different types may co-develop in a single shrimp, as reported for other crustaceans (Bonami 1980, Mari 1987, Krol et al. 1990). All the results presented here support the hypothesis that different BP-type baculoviruses infect penaeid shrimp, and that DNA probes can be used to differentiate between at least 2 BP strains.

Acknowledgements. Partial funding for this work was provided by the Gulf Coast Consortium, Marine Shrimp Farming Program, Cooperative State Research, Education and Extension Service, U.S. Dept. of Agriculture.

\section{LITERATURE CITED}

Bell TA, Lightner DV (1988) A handbook of normal penaeid shrimp histology. World Aquaculture Society, Baton Rouge

Bonami JR (1980) Recherche sur les infections virales des crustacés marins: études des maladies à étiologie simple et complexe chez les décapodes des côtes françaises.

Editorial responsibility: Tim Flegel,

Bangkok, Thailand
Thèse Doctorale d'Etat, Univ Sci Tech Languedoc, Montpellier

Bonami JR, Bruce LD, Poulos BT, Mari J, Lightner DV (1995) Partial characterisation and cloning of the genome of PvSNPV \{=BP-type virus) pathogenic for Penaeus vannamei. Dis Aquat Org 23:59-66

Bruce LD, Redman RM, Lightner DV, Bonami JR (1993) Application of gene probes to detect a penaeid shrimp baculovirus in fixed tissue using in situ hybridization. Dis Aquat Org 17:215-221

Couch JA (1974a) An enzootic nuclear polyhedrosis virus of pink shrimp: ultrastructure, prevalence, and enhancement. J Invertebr Pathol 24:311-331

Couch JA (1974b) Free and occluded virus, similar to Baculovirus, in hepatopancreas of pink shrimp. Nature 247 . 229-231

Krol RM, Hawkins WE, Overstreet RM (1990) Reo-like virus in white shrimp Penaeus vannamei (Crustacea: Decapoda): co-occurrence with Baculovirus penaei in experimental infections. Dis Aquat Org 8:45-49

Lightner DV, Redman RM. Williams RR, Mohney LL, Clerx. JPM. Bell TA, Brock JA (1985) Recent advances in peneaid virus disease investigations. $J$ World Maricult Soc $16: 264-274$

Mari J (1987) Recherche sur les maladies virales du crustacé décapode marin Carcinus mediterraneus Czerniavski 1884. Thèse Doctorat, Univ Sci Tech Languedoc, Montpellier

Summers MD (1977) Characterization of shrimp baculovirus. Ecological Research Series, EPA-600/3-77-130

Submitted: September 5, 1997; Accepted: November 28, 1997 Proofs received from author(s): March 6, 1998 